\title{
Association of cystic fibrosis with allergy
}

\author{
J. O. WARNER, B. W. TAYLOR, A. P. NORMAN, and J. F. SOOTHILL \\ From the Hospital for Sick Children, London
}

\begin{abstract}
Warner, J. O., Taylor, B. W., Norman, A. P., and Soothill, J. F. (1976). Archives of Disease in Childhood, 51, 507. Association of cystic fibrosis with allergy. Immediate skin hypersensitivity to various inhalant allergens was present in $59 \%$ of 123 children with cystic fibrosis (CF), a much higher percentage than in the general population. This is consistent with the idea that atopy arises as a result of impaired handling of antigen at mucosal surfaces. The allergic CF children had more chest infections, a worse chest $x$-ray appearance, and lower peak expiratory flow rates. Allergic diseases were also frequent in the CF obligate heterozygotes $(32 \%$ of mothers and $26 \%$ of fathers). It is suggested that the heterozygotes may also have a mucosal abnormality resulting in defective antigen handling.
\end{abstract}

The suggestion that atopy may result from excessive stimulation of the IgE-producing cells because of failure of antigen exclusion at mucosal surfaces is supported by the observation that much infantile atopy is preceded by IgA deficiency (Taylor et al., 1973). This is consistent with the view that antigen exclusion is, in part, dependent on immune reactions. However, it is possible that other abnormalities of mucosal function might have a similar effect. We have therefore undertaken a study of allergy in cystic fibrosis $(\mathrm{CF})$. This paper reports the first results of an on-going project.

\section{Patients and methods}

The 123 children with CF studied were sequential attenders at the CF clinic of this hospital, which caters for about 150 patients. Those excluded from assessment either did not wish to be included or were not available at the time of study. There were 45 girls and 78 boys whose ages ranged from 4 months to 17 years. The diagnosis of CF was established by the clinical history and a sweat sodium concentration greater than $70 \mathrm{mEq} / \mathrm{l}$. The range of clinical presentations (Table I) was fairly characteristic of the condition.

Parents were questioned in detail about their child's respiratory symptoms and the occurrence of allergic phenomena. Family histories of atopic diseases were also recorded. The information was recorded on a standard questionnaire. All children were examined and skin-prick tested, either on the forearms or back, with 12 Bencard skin test antigens (Table II) and a control solution. Reactions were examined at 20 minutes and were considered positive when a flare reaction was greater than $5 \mathrm{~mm}$ diameter and a wheal

Received 24 October 1975.
TABLE I

Clinical presentation of 123 children at initial diagnosis of cystic fibrosis related to subsequent skintest findings

\begin{tabular}{l|c|c|c}
\hline \multirow{1}{*}{ Presentation } & Total & \multicolumn{2}{|c}{ Skin test } \\
\cline { 3 - 4 } & & Positive & Negative \\
\hline $\begin{array}{l}\text { Chest, with or } \\
\text { without bowel } \\
\text { symptoms }\end{array}$ & & & \\
Meconium ileus & 66 & 42 & 24 \\
Bowel symptoms & 25 & 15 & 10 \\
$\quad$ alone & 25 & 12 & 13 \\
Sib screen & 6 & 3 & 3 \\
Nasal polyps & 1 & 1 & 0 \\
\hline Total & 123 & 73 & 50 \\
\hline
\end{tabular}

greater than $3 \mathrm{~mm}$ diameter. No patients reacted to the control solution.

Also noted were the latest chest $x$-ray findings (PA and lateral), using an evaluation score (Chrispin and Norman, 1974), peak expiratory flow rates measured with a Wright peak flow meter; and thoracic gas volumes measured by total body plethysmography within the previous 6 months.

\section{Results}

Of the 123 CF children 73 (59\%) had immediate skin sensitivity to one or more allergens. The proportion of positive reactions was similar in boys and girls (Table III). The mean age of presentation was similar in the two groups $(1.57$ and 1.64 years respectively), though the age at the time of testing was older in the allergic group $(8.9$ com- 
TABLE II

Skin sensitivities of allergic CF patients compared with those of allergy clinic patients

\begin{tabular}{|c|c|c|c|c|c|c|c|}
\hline \multirow{2}{*}{ Allergens } & \multicolumn{3}{|c|}{ Allergic CF patients } & \multicolumn{3}{|c|}{ Allergy clinic patients } & \multirow{2}{*}{$\begin{array}{c}\chi^{2} \text { test for } \\
\text { significance } \\
\text { of group } \\
\text { differences } \\
P\end{array}$} \\
\hline & No. positive & No. negative & $\%$ positive & No. positive & No. negative & $\%$ positive & \\
\hline $\begin{array}{l}\text { House dust extract } \\
\text { Dermatophagoides pteronyssinus } \\
\text { Dermatophagoides furinae } \\
\text { Feathers } \\
\text { Cat fur } \\
\text { Dog hair } \\
\text { Whole egg } \\
\text { Milk } \\
\text { Timothy grass } \\
\text { Rye grass } \\
\text { Aspergillus fumigatus } \\
\text { Cladosporium }\end{array}$ & $\begin{array}{r}24 \\
18 \\
17 \\
16 \\
12 \\
10 \\
3 \\
7 \\
41 \\
39 \\
41 \\
23\end{array}$ & $\begin{array}{l}49 \\
55 \\
56 \\
57 \\
61 \\
63 \\
70 \\
66 \\
32 \\
34 \\
32 \\
50\end{array}$ & $\begin{array}{r}33 \\
25 \\
23 \\
22 \\
16 \\
14 \\
4 \\
10 \\
56 \\
53 \\
56 \\
31\end{array}$ & $\begin{array}{r}194 \\
222 \\
224 \\
69 \\
89 \\
56 \\
10 \\
14 \\
- \\
5 \\
35\end{array}$ & $\begin{array}{r}113 \\
85 \\
83 \\
217 \\
64 \\
94 \\
83 \\
80 \\
- \\
25 \\
223\end{array}$ & $\begin{array}{l}63 \\
72 \\
73 \\
24 \\
58 \\
37 \\
11 \\
15 \\
- \\
17 \\
14\end{array}$ & $\begin{array}{c}<0.001 \\
<0.001 \\
<0.001 \\
N S>0.05 \\
<0.001 \\
<0.001 \\
N S>0.05 \\
N S>0.05 \\
\quad- \\
<0.001 \\
<0.001\end{array}$ \\
\hline
\end{tabular}

TABLE III

Skin reactivity related to sex in $C F$ patients

\begin{tabular}{l|c|c|c|c}
\hline & \multicolumn{2}{|c|}{ Skin test positive } & \multicolumn{2}{c}{ Skin test negative } \\
\cline { 2 - 4 } & No. & $\%$ & No. & $\%$ \\
\hline Boys & 44 & 56 & 34 & 44 \\
Girls & 29 & 64 & 16 & 36 \\
\hline Total & 73 & 59 & 50 & 41 \\
\hline
\end{tabular}

pared with 7.9 years). The incidence of positive reactions to each of the allergens is compared in Table II with the incidence in children attending the hospital allergy clinic during 1973 and 1974, mainly for asthma and allergic rhinitis. The incidence of reactions to house dust and mite, cat fur, and dog hair was significantly lower and the incidence of reactions to mould allergens significantly higher in the CF patients who reacted to any antigen. Three patients reacted to 11 or 12 of the antigens, 16 reacted to only 1 , and 41 reacted to one or both moulds -8 of them reacting to mould antigen alone.

The range of possible allergic symptoms in relation to skin reactivity (Table IV) occurred frequently in both groups; more hay fever sufferers were skin-test positive. More of the CF allergic cases presented with chest symptoms (Table I), though the difference was not significant, whereas for other presentations the incidences were equal.

A high proportion of the allergic group had repeated (more than two) severe chest infections requiring hospital admission during the period of medical supervision (Table V). Bacteria isolated from serial sputum specimens taken at two-monthly
TABLE IV

Possible allergic symptoms of CF patients related to skin reactivity

\begin{tabular}{l|c|c}
\hline \multirow{2}{*}{ Allergic symptoms } & \multicolumn{2}{|c}{ Skin test } \\
\cline { 2 - 3 } & Positive & Negative \\
\hline Wheezing with infections & 36 & 18 \\
Wheezing at other times & 19 & 9 \\
Hay fever & $16^{\star}$ & $4^{\star}$ \\
Urticaria & 13 & 5 \\
Eczema & 10 & 4 \\
Perennial rhinitis & 11 & 12 \\
Drug allergy & 6 & 4 \\
Food allery & 2 & 6 \\
Nasal polyps & 3 & 5 \\
\end{tabular}

^Significant difference; $\mathbf{P}<0.05$.

intervals in the outpatient clinic did not obviously differ, and Pseudomonas aeruginosa was isolated repeatedly from the sputum of similar numbers of cases in each group.

All the patients with the most abnormal chest $x$-ray findings were allergic (Fig. 1). Since there are many ties at the lower levels of abnormality ranking tests are insensitive in testing the difference, but if we apply a $x^{2}$ test for patients with chest $x$-ray scores $>$ or $<15$ the difference is significant (Table V).

Figs. 2 and 3 show the distributions of peak expiratory flow (PEF) and thoracic gas volume (TGV) by height (cm) for the allergic and nonallergic patients. There is a tendency for all CF patients to have lung overinflation (high TGV), becoming greater with increasing height (that is, age) with no obvious difference between the two groups. The PEFs have fallen predominantly within the normal range, but significantly more allergic patients 
TABLE V

Skin reactivity related to various factors

\begin{tabular}{|c|c|c|c|c|c|c|c|}
\hline & $\begin{array}{l}\text { Breast fed } \\
>3 / 12\end{array}$ & $\begin{array}{c}\text { CXR score } \\
>15\end{array}$ & $\begin{array}{l}\text { Pseudomonas } \\
\text { in sputum }\end{array}$ & $\begin{array}{c}\mathrm{TGV}>2 \mathrm{SD} \\
\text { above mean }\end{array}$ & $\begin{array}{c}\mathrm{PEF}>2 \mathrm{SD} \\
\text { below mean }\end{array}$ & $\begin{array}{c}2 \text { Severe chest } \\
\text { infections }\end{array}$ & $\begin{array}{l}\text { No severe chest } \\
\text { infections }\end{array}$ \\
\hline $\begin{array}{l}\text { Skin test positive } \\
\text { Skin test negative }\end{array}$ & $\begin{array}{r}12 \\
4\end{array}$ & $\begin{array}{r}14 \\
3\end{array}$ & $\begin{array}{l}36 \\
19\end{array}$ & $\begin{array}{l}23 \\
10\end{array}$ & $\begin{array}{r}11 \\
1\end{array}$ & $\begin{array}{l}37 \\
21\end{array}$ & $\begin{array}{r}6 \\
19\end{array}$ \\
\hline $\begin{array}{l}\chi^{2} \\
P \text { value }\end{array}$ & $\begin{array}{l}1 \cdot 87 \\
\text { NS }\end{array}$ & $\begin{array}{r}4 \cdot 33 \\
<0.05\end{array}$ & $\begin{array}{l}1 \cdot 54 \\
\text { NS }\end{array}$ & $\begin{array}{l}0.58 \\
\text { NS }\end{array}$ & $\begin{array}{r}4.82 \\
<0.05\end{array}$ & \multicolumn{2}{|c|}{$\begin{array}{l}11 \cdot 08 \\
<0.001\end{array}$} \\
\hline
\end{tabular}

$\mathrm{CXR}=$ chest $x$ ray. $\mathrm{TGV}=$ thoracic gas volume. $\quad$ PEF $=$ peak expiratory flow.

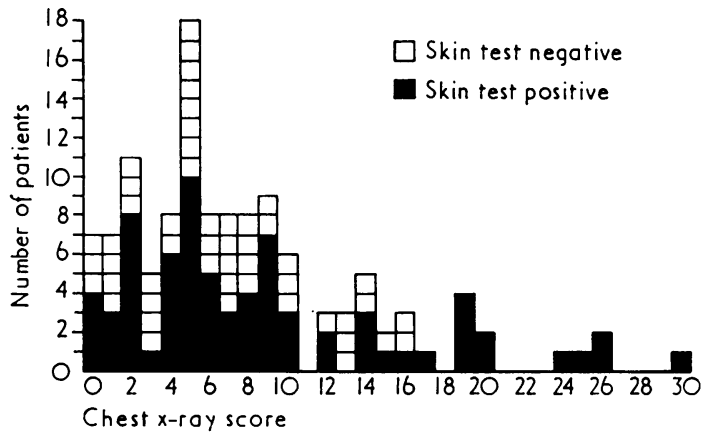

FIG. 1.-Chest $\mathrm{x}$-ray scores in skin-test positive and skintest negative patients.

had PEF values below the 3rd centile. Breastfeeding made no difference to the incidence of allergy, more children being breast-fed for 3 months or more in the allergic group (Table V), though we do not know how many received cows' milk supplements during the immediate postnatal period.

A history of allergic disease was found among the first-degree relatives in 65 of 114 families investigated (9 families had 2 CF children). Out of the obligate heterozygotes 36 of 114 (32\%) mothers and 30 of $114(26 \%)$ fathers had a history of asthma, hay fever, or urticaria.

\section{Discussion}

Many features are common to both cystic fibrosis and respiratory allergy, including rhinitis, nasal polyps, cough, wheeze, and lung hyperinflation. Day and Mearns (1973) found an abnormal bronchial lability in patients with CF, and many authors (Lifschitz and Denning, 1969; Featherby, Weng, and Levison, 1970; Chang and Levison, 1972; Landau and Phelan, 1973; Rothstein et al., 1974) have reported that pulmonary function in some CF children improves with bronchodilators. The coexistence of asthma or hay fever, or both, with $\mathrm{CF}$ is well recognized, the incidence ranging from

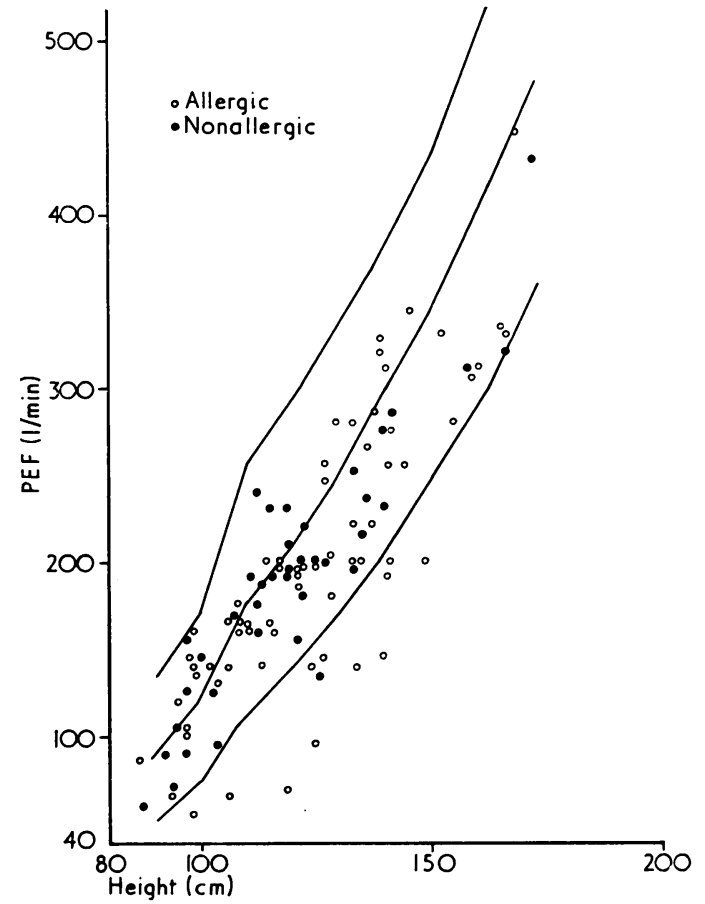

FIG. 2.-Peak expiratory flow rates (PEF) plotted against height for allergic and nonallergic $C F$ patients (expected mean and $2 S D$ lines indicated).

10 to $24 \%$ in various studies (Van Metre et al., 1960; Kulczycki, Mueller and Shwachman, 1961; Rachelefsky et al., 1974). This compares with the incidence of respiratory allergy in the general population of $7-20 \%$ (Blair, 1974; Carr, Berke, and Becker, 1964). However, the authors of these studies, while suggesting a slightly increased incidence of allergic disease in CF, were inclined to the view that the two were occurring coincidentally.

Warren et al. (1975), in a systematic study of atopic manifestations in CF, showed that $70 \%$ 


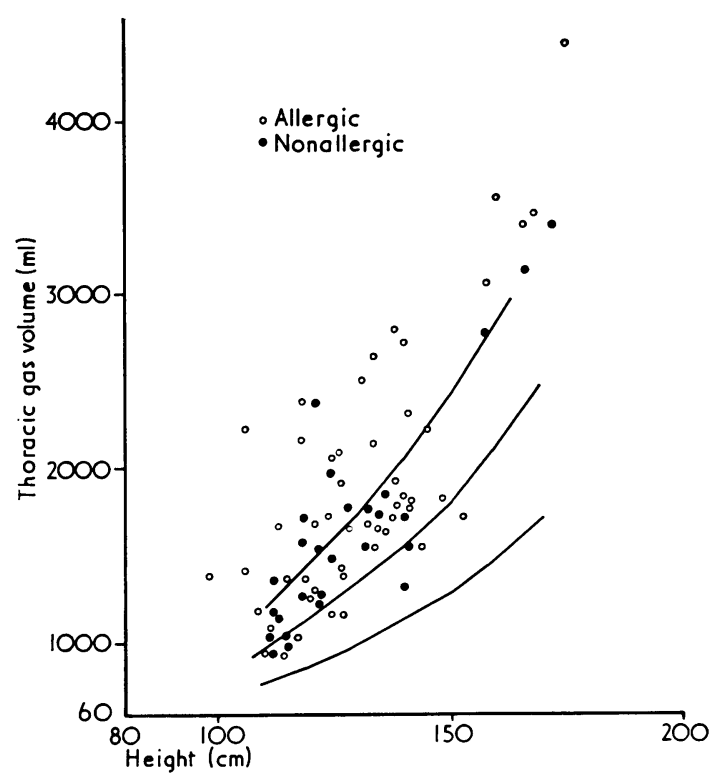

FIG. 3.-Thoracic gas volume plotted against height for allergic and non-allergic CF patients (expected mean and 2 SD lines indicated).

of their 43 patients had cutaneous sensitivity to a variety of allergens. Our study shows that $59 \%$ of CF children have allergy manifested by skin sensitivity to a variety of antigens. Our control series is still incomplete, but a study by Horn and Gregg (1973) gave an incidence of positive skin tests of only $23 \%$ in nonasthmatic children. The spectrum of allergen sensitivities is different to that found in other allergic populations. There is a very high incidence of Aspergillus fumigatus and other mould (Cladosporium) sensitvities; as has been reported by others (Craco et al., 1974; Mearns, Longbottom, and Batten, 1967). House dust mite and animal dander allergies are less prominent.

Possibly there is a different reaginic process in the CF cases, in association with the differing sensitivities. However, Wallwork et al. (1974) found a raised serum IgE in $32 \%$ of CF cases and Warren et al. (1975) found IgE antibodies corresponding to positive prick-test reactions in their CF patients. An alternative explanation for the odd distribution of allergies could be related to the mechanical properties of the lungs of $\mathrm{CF}$ patients. Mould spores, particularly those from $A$. fumigatus, are very small and could be inhaled by a normal lung without being deposited on the mucosal surfaces of the airways. However, the air trapping that occurs in a persistently infected CF lung might be enough to trap mould spores in the airways with the result that sensitization could occur with production of IgE antibodies.

Allergy might confer some protective mechanism on CF patients resulting in less chest disease (Rachelefsky et al., 1974). Our allergic cases had a higher incidence of repeated severe chest infections, of worse chest $x$-ray appearances, and of reduced PEF rates. They also tended to present more often with chest symptoms. Three possible explanations of these findings are either that CF with respiratory allergy might result in worse chest disease, or that the chest infections might cause a mucosal abnormality which allows penetration of allergens leading to sensitization, or that there is a mucosal defect in CF which results in both a susceptibility to chest infections and the development of allergy. It has been shown, for instance, that persons possessing the CF gene (homozygote or heterozygote) have a serum factor which causes ciliary dyskinesis in vitro (Spock et al., 1967; Bowman, Lockhart, and McCombs, 1969). Perhaps this factor has a similar effect in vivo, resulting in failure to sweep foreign substances, bacteria, and allergens from the respiratory tract. Thus both excessive infection and an increased incidence of allergy might be expected.

The study also shows a high incidence of allergic symptoms related to skin response. Thus treatment of allergic symptoms by allergen avoidance, bronchodilators, disodium cromoglycate and, possibly, hyposensitization is logical, though we have no evidence to support this. Also the diagnosis of CF should be considered in all intermittently wheezy children with positive skin tests before they are accepted as being asthmatic.

Unlike other series, ours showed a surprisingly high incidence of a history of allergic disease among first-degree relatives of CF cases. Our figures are probably an underestimate of the incidence of allergy, as only clear cut histories were accepted and we did not perform skin tests on the relatives. Perhaps the heterozygotes also have a mucosal abnormality such as ciliary dyskinesis which results in inadequate clearing of the antigen from the lungs, thus allowing sensitization to occur. Since 1 in 20 of the population are CF heterozygotes this could account for a sizeable portion of allergy in the community. Furthermore, an assessment of atopic status might be a useful adjunct when screening for CF heterozygosity.

We thank Miss Christine Vincent for the secretarial work and the patients and their parents for their willing co-operation in this study. 
REFERENCES

Blair, H. (1974). The incidence of asthma, hay fever and infantile eczema in an East London group practice of 9145 patients. Clinical Allergy, 4, 389.

Bowman, B. H., Lockhart, K. H., and McCombs, M. L. (1969). Oyster ciliary inhibition by cystic fibrosis factor. Science, 164, 325.

Carr, R. D., Berke, M., and Becker, W. S. (1964). Incidence of atopy in the general population. Archives of Dermatology, 89, 27.

Chang, N., and Levison, H. (1972). The effect of a nebulized bronchodilator administered with or without intermittent positive pressure breathing on ventilatory function in children with cystic fibrosis and asthma. American Review of Respiratory Disease, $106,867$.

Chrispin, A. R., and Norman A. P. (1974). The systematic evaluation of the chest radiograph in cystic fibrosis. Pediatric Radiology, 2, 101.

Cracco, G., Andri, G., Bonom, U., Faggionato, P., Mastella, G., Piacentini, I., Tonon, S., and Mengoli, V. (April, 1974). Hypersensitivity to fungi in cystic fibrosis. European Working Group for Cystic Fibrosis (Abst.), p. 16.

Day, G., and Mearns, M. B. (1973). Bronchial lability in cystic fibrosis. Archives of Disease in Childhood, 48, 355.

Featherby, E. A., Weng, T-R., and Levison, H. (1970). The effect of isoproterenol on airway obstruction in cystic fibrosis. Canadian Medical Association fournal, 102, 835.

Horn, M. E. C., and Gregg, I. (1973). Role of viral infection and host factors in acute episodes of asthma and chronic bronchitis. Chest, 63, Suppl. 44.

Kulczycki, L. L., Mueller, H., and Shwachman, H. (1961). Respiratory allergy in patients with cystic fibrosis. Fournal of the American Medical Association, 175, 358.

I andau, L. I., and Phelan, P. D. (1973). The variable effect of a bronchodilating agent on pulmonary function in cystic fibrosis. Fournal of Pediatrics, 82, 863.
Lifschitz, M. I., and Denning, C. R. (1969). Assessment of bronchospasm in patients with cystic fibrosis. American Review of Respiratory Disease, 99, 399.

Mearns, M. B., Longbottom, J., and Batten, J. (1967). Precipitating antibodies to aspergillus fumigatus in cystic fibrosis. Lancet, 1 , 538.

Rachelefsky, G. S., Osher, A. Dooley, R. E., Ank, B., and Stiehm, E. R. (1974). Co-existent respiratory allergy and cystic fibrosis. American fournal of Diseases of Children, 128, 355.

Rothstein, R. J., Pinney, M. A., Buckley, J. M., and Cotton, E. K. (1974). Evaluation of reactive airway disease in atopic cystic fibrosis patients. Fournal of Allergy and Clinical Immunology, $53,100$.

Spock, A., Heick, H., Cress, H., and Logan, W. (1967). Abnormal serum factor in patients with cystic fibrosis of the pancreas. Pediatric Research, 1, 173.

Taylor, B., Norman, A. P., Orgel, H. A., Stukes, C. R., Turner, M. W., and Soothill, J. F. (1973). Transient IgA deficiency and pathogenesis of infantile atopy. Lancet, 2, 111.

Van Metre, T. E., Couke, R. E., Gibson, L. E., and Winkenwerder, W. L. (1960). Evidence of allergy in patients with cystic fibrosis of the pancreas. Fournal of Allergy and Clinical Immunology, 31, 141.

Wallwork, J. C., Brenchley, P., McCarthy, J., Allan, J. D., Moss, D., Milford Ward, A., Holzel, A., Williams, R. F., and McFarlane, H. (1974). Some aspects of immunity in patients with cystic fibrosis. Clinical and Experimental Immunology, 18, 303.

Warren, C. P. W., Tai, E., Batten, J. C., Hutchcroft, B. T., and Pepys, J. (1975). Cystic fibrosis-immunological reactions to aspergillus fumigatus and common allergens. fournal of Clinical Allergy, $1,1$.

Correspondence to Dr. J. O. Warner, the Hospital for Sick Children, Great Ormond Street, London WC1 $3 \mathrm{JH}$. 